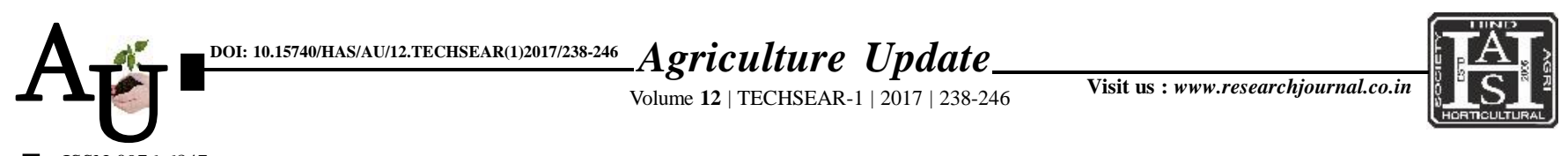

— e ISSN-0976-6847

\title{
Research Article: Integrated management of stem rot and pod rot (Sclerotium rolfsii) of groundnut (Arachis hypogaea L.)
}

Article Chronicle : Received : 11.07.2017;

Accepted :

26.07.2017

KeY Words :

Arachis hypogaea, Bioagents, Botanicals, Fungicides, Organic and inorganic amendments, Sclerotium rolfsii

Author for correspondence :

\section{D.P. KULDHAR}

Department of

Agricultural

Entomology, Vasantrao

Naik Marathwada

KrishiVidyapeeth,

PARBHANI (M.S.) INDIA

Email:dinkumar007@

gmail.com

See end of the article for authors' affiliations

\section{D.P. KULDHAR AND A.P. SURYAWANSHI}

SUMMARY : The studies were carried out on stem rot and pod rot caused by Sclerotium rolfsii Sacc. on Groundnut (Arachis hypogaea L.), at Vasantrao Naik Marathwada Krishi Vidyapeeth, Parbhani. The in-vitro evaluation (@ 1000,1500 and 2000 ppm) revealed highest average mycelial growth inhibition with fungicides, Thiram + Carbendazim (96.31\%), Carbendazim (95.26\%) and Thiram (94.80\%). Of the bioagents evaluated, significantly highest mycelial growth inhibition was recorded with $T$. harzianum (78.37\%), T. viride (74.70\%) and T. hamatum (73.96\%). Aqueous extracts of all botanicals tested (@ 10, 15 and 20\%) exhibited antifungal potential and significantly highest average mycelial growth inhibition was recorded with Azadirachta indica (70.02 \%), Z. officinale (66.58 \%) and P. hysterophorus $(65.52$ $\%)$. Significantly highest seed germination $(98.33 \%)$ was recorded with the treatment Thiram + Carbendazim $+T$. harzianum $+P$. fluorescens $+\mathrm{NSC}+$ A. indica extract. Significantly highest reduction in pre-emergence $(97.61 \%)$, post-emergence $(95.77 \%)$ and average $(96.69 \%)$ mortality were recorded with treatment of Thiram + Carbendazim + T. harzianum + P. fluorescens + NSC $+A$. indica extract. Thus, it is concluded that groundnut stem rot and pod rot can be managed effectively by seed treatment with fungicides (Thiram, Carbendazim), bioagent (T. harzianum + P. fluorescens) and soil amendment with Neem seed cake + A. indica extract.

How to cite this article : Kuldhar, D.P. and Suryawanshi, A.P. (2017). Integrated management of stem rot and pod rot (Sclerotium rolfsii) of groundnut (Arachis hypogaea L.). Agric. Update, 12(TECHSEAR-1) : 238-246; DOI: 10.15740/HAS/AU/12.TECHSEAR(1)2017/238-246. 